Working Paper No. 595, 2003

\title{
An Essay on Welfare State Dynamics
}

by Assar Lindbeck

IUI, The Research Institute of Industrial Economics

P.O. Box 5501

SE-114 85 Stockholm

Sweden 
$15 / 5,2003$

Assar Lindbeck:

\section{An Essay on Welfare State Dynamics}

Abstract

The expansion of welfare-state arrangements is seen as the result of dynamic interaction between market behaviour and political behaviour, often with considerable time lags, sometimes generating either virtuous or vicious circles. Such interaction may also involve induced (endogenous) changes in social norms and political preferences. Moreover, the internationalisation process not only limits the ability of national governments to redistribute income; they also increase the political demands for international mobility of welfare-state benefits and social services. I also discuss the dynamics of reforms and retreats of welfare-state arrangements.

JEL Classification number: H1, H5

Keywords: welfare state, welfare-state dynamics, political equilibrium, social norms

I am grateful to Tore Ellingsen for useful comments to an earlier version. 
It is useful to discuss welfare-state arrangements and their consequences in the context of dynamic processes, with the development in one period critically influencing subsequent developments. For instance, the expansion of welfare-state arrangements during the $20^{\text {th }}$ century may be seen as the result of dynamic interaction between market behaviour and political behaviour over time, often with considerable time lags (section I). Such interaction may also result in either virtuous or vicious spirals (section II). Moreover, welfare-state dynamics may involve induced (endogenous) changes in social norms and political preferences, which also tend to occur only after considerable time lags (section III). Finally, I make some comments on the dynamics of reforms and retreats of welfare-state arrangements (section IV).

Clearly, theory and speculation are far 'ahead' of systematic empirical research in the field of welfare-state dynamics. This paper may partly be seen as a call for more empirical research in the field.

\section{THE EXPANSION OF WELFARE-STATE ARRANGEMENTS}

Generally speaking, welfare-state arrangements are, of course, meant to enhance income security and provide social ('human') services for broad population groups, as well as mitigate poverty. In some countries, welfare-state arrangements, and the taxes to finance them, have also been designed to compress the overall distribution of disposable income. Against this background, it is easy to understand that welfare-state spending was boosted by the emergence of general franchise in the western countries in the early $20^{\text {th }}$ century, since this strengthened the political voice of low- and middleincome groups.

But why did it then take about half a century to build up elaborate welfare-state arrangements? One explanation may be that organizing and mobilizing new voters in the political process takes considerable time. Another reason is that there was only a gradual increase in the interest among voters for formal systems of income protection and personal services outside the family. Naturally, I refer to the industrialization process, which over time increased the demand for formal arrangements of income protection in the case of unemployment, sickness and retirement and so on. Moreover, due to the urbanisation process, which separated family members geographically, the family gradually became less able to provide income protection and human services to its members. 
Thus, expanded welfare state spending may be seen as a combined effect of discrete shifts of political (electoral) powers, a gradual mobilisation of new voters, and a rising interest among the population in new institutional arrangements of income security and social services. It is also likely that the demand for income protection and social services tends to rise more than income (an income elasticity greater than one). An additional explanation of the observed gradualism may be the uncertainty about the economic and social consequences of new welfare-state arrangements, and their financing. In this sense, gradualism also reflects an experimental process, with information feedback from previous policy experiments.

Gradualism is, however, also a result of capacity limitations in political decision-making, which means that decisions must necessarily be recursive (sequential) rather than simultaneous. Indeed, such 'incrementalism' has been much discussed in the political science literature; see, for instance, Wildavsky (1984). This recursivity of political decision-making interacts with the well-known fact that benefits are usually more selective, that is more group-specific, than taxes, which means that the per capita gain for beneficiaries is greater than the per capita income loss for tax payers. Metaphorically speaking, in January group A is offered (or asks for) a special benefit at the expense of the general taxpayer, in February group B, in March group C, and so on. A specific interest group may also push for new benefits to itself in response either to previously increased benefits to others or in anticipation of such benefits in the future (Lindbeck 1985). A recursive political process of this type may keep aggregate government spending gradually rising (as a share of GNP) for a long period of time.

It is sometimes also argued that welfare-state spending is systematically influenced by constitutional rules and other institutional arrangements. Indeed, there is empirical evidence that proportional (as compared to majority) voting, strong unions and social-democratic or Christian-democratic political dominance tend to boost such spending (Pierson 2001, Persson and Tabellini 2002). There is also evidence that majority voting tends to result in a structure of spending that favours special interest groups, as compared to political regimes with proportional voting (Persson and Tabellini, 2002).

The structure of new welfare-state arrangements also seems to critically depend on the previously chosen structure - that is on a country's previous choice of 'welfare regime' (in Esping-Andersen's terminology, 1990). In other words, there is strong 'history dependence' of the welfare regime. For instance, in several countries on the 
European continent, high minimum wages, rigid relative wages, high payroll taxes, generous and long-lasting unemployment benefits and strict job-security legislation, introduced in the 1960s and 1970s, have contributed to unemployment persistence, with a pronounced insider-outsider divide in the labour market, in particular for lowproductivity workers (Lindbeck and Snower 1988, Lindbeck 1996). A usual policy response in the late 1970s and early 1980s was to make the unemployment benefits even more generous, further strengthen the job-security legislation, and (in particular) encourage early retirement. To counteract tendencies to large budget deficits, governments often further raised payroll taxes which, in some cases, contributed to a new round of redundancies among low-productivity workers and hence to more outsiders.

In the Nordic countries, expanded public-sector employment and so-called active labour market policies (such as public works and retraining programs) have largely taken care of labour-market outsiders. Thus, while countries on the continent have experienced 'welfare without work', in the Nordic countries the result has rather been large public-sector employment.

In Anglo Saxon countries, without much ambition to push up the wage costs for low-skilled workers, and with low unemployment benefits and little legislated job security, the 'continental' insider-outsider divide has largely been avoided. It has, however, been replaced by a large number of 'working poor' - a phenomenon accentuated by the poor education and training of individuals at the low end of the labour market (as compared to many European countries). This, in turn, constitutes the background for recent policies in the United States and the United Kingdom to introduce and expand employment subsidies for low-wage workers (so-called 'in-work benefits'), rather than subsidizing non-work (as on the European continent) or increased public-sector employment (as in the Nordic countries). This is another example of history dependence of welfare regimes.

Interdependencies between family structure and welfare-state arrangements are another example of dynamics in connection with the expansion of the welfare state. For instance, the welfare regimes on the European continent have traditionally been designed to fit families with a single 'male-breadwinner', which means that such regimes are rather poorly adjusted to the contemporary ambitions of females to participate in the labour market. The limited provision of childcare and old-age care outside the family in these countries is an important example. The resulting low number 
of females in the labour force, in turn, helps explain the limited political pressure for government arrangements in the fields of child care and old-age care - another example of mutual interaction of market behaviour and political behaviour.

In contrast, in the Nordic countries, high subsidies of child care and old-age care may be seen both as a cause and an effect of the rapid increase in female labour-force participation. High average tax rates for most individuals have further boosted female labour force participation, although usually on a part-time basis. It has simply become difficult to finance a family with small children with a single income earner (reflecting a positive income effect, or perhaps rather liquidity effect, of household taxes on the labour supply of females). The labour supply of married women has been further stimulated by shifts to an individual rather than a family assessment of income taxes, which has mitigated the rise in the marginal tax rate for females in countries with progressive taxes. Moreover, subsidies of childcare and old-age care outside the family are presumably an important explanation why nativity in the Nordic countries is not lower, indeed often somewhat higher, than in European countries, where female labour force participation is smaller.

There may, however, also be serious problems with large subsidies of child-care and old-age care, the most obvious one being that they contribute to high taxes and hence, large tax distortions. In Sweden and Norway, it has also been hypothesised that not only single parents but also families with two adult income earners (with children), in many cases run into serious time constraints. This is asserted to be the case for females, in particular, who still have the main responsibility for children and household work. The high marginal tax rates and the high relative wages for personal services make it difficult to afford such services in the market. For instance, if both I myself and a potential supplier of personal services have a marginal tax rate of 50 per cent, I would have to earn four times as much before tax as the service supplier gets after tax. As a result, the 'legal' market for household services tends to break down. The ensuring scarcity of time among adult family members is sometimes assumed to be an important explanation for stress symptoms, and the exceptionally high level of sick leave in Norway and Sweden, in particular among females. ${ }^{1}$ Some evidence for this assertion is that the (medically measured) stress level among females with 'double work' seems to

\footnotetext{
${ }^{1}$ In 1992, the average number of sick days in Sweden has been estimated to about 30 per year. The figure for females is about 50 per cent higher than for men (according to the statistics from previous years); see Persson (2003).
} 
reach its daily peak after work, rather than during the workday (Frankenhaeuser et al. 1991).

Families in the United States have been able to combine high female labour force participation, often in the form of full time work, with a considerably higher nativity than most other developed countries (including the Nordic ones). One explanation may be that many high-and medium-income families in the United States save time by being able to buy personal services in the market, since relatively low average taxes implies high disposable income, and since low marginal tax rates and a dispersed wage distribution make such services inexpensive for such families. This has presumably dampened the political pressure for generous government subsidies of childcare and old-age care - although there is much complaint also in the US about the scarcity of inexpensive services of these types.

\section{VIRTUOUS AND VICIOUS WELFARE-STATE DYNAMICS}

Certain types of dynamic interdependencies between welfare-state arrangements and private behaviour may be characterised as virtuous spirals. Such dynamics were highlighted in Gunnar Myrdal's (1944, Appendix 3) classical study of socio-economic developments among the black population in the United States in the 1930s. Myrdal emphasized what he called processes of 'cumulative causation' among socio-economic characteristics, in terms of 'employment, wages, housing, nutrition, clothing, health, education, stability in the family relations, manners, cleanliness, orderliness, trustworthiness, law observance, loyalty to society at large, absence of criminality, and so on'. In Myrdal's view, certain types of welfare state policies may turn vicious social spirals into virtuous ones, in particular, if the policies operate simultaneously on several social phenomena.

Today, there is broad empirical support for the relevance of Myrdal's vision of virtuous spirals in response to policies designed to improve the quality and quantity of human capital among low-income groups, in particular in developing countries. The most obvious examples might be improved elementary education, better nutrition and sanitation, and fewer incidents of infectious deceases; see references in Lindbeck (2003). Indeed, there is evidence of such childhood improvements being transmitted to future generations. Since government spending to boost human capital in these fields 
also tends to expand the future tax base, via higher labour productivity, such spending may even be self-financing for the government in a long perspective.

It is often also hypothesised that welfare-state arrangements may contribute to social and political stability, and that this tends to favour real investment and economic growth. Indeed, Alesina and Rodrik (1994) find empirical support for this hypothesis in cross-country regressions covering both poor and rich countries. In a somewhat similar fashion, Persson and Tabellini (1994) find empirical support for the hypothesis that a reduced dispersion of factor income ('gross income' before taxes and transfers) is favourable to economic growth for a large sample of poor and rich countries. ${ }^{2}$

It is, however, widely (and realistically) believed among economists that the relation between government spending, on one hand, and economic efficiency and growth, on the other hand, is hump-shaped rather than monotonous. In rich countries, where government spending has already reached high levels (as a share of GNP), there is, therefore, a possibility that a further rise in government spending would move the economy into the downward-sloping part of the 'hump'. Nevertheless, special interest groups may be able to push through such spending increases in the context of the recursive political process outlined above. Thus, there may be an 'overshooting' of government spending in the sense that a majority of voters would have preferred lower aggregate spending - if it had been politically and administratively feasible to take all spending decisions simultaneously rather than sequentially (Lindbeck 1985 and 1994). The emergence of such an overshooting of welfare-state spending, then, assumes that the sequential nature of the political process makes coordination of group demands impossible (a coordination failure), alternatively that voters and/or politicians do not rationally anticipate the disincentive effects of welfare state policies (cognitive limitations). The widely held view in the 1990 s and early 2000 s that it is important to cut welfare-state spending indicates the existence of such overshooting.

Overshooting is more likely in countries with so-called 'universal' welfare-state arrangements covering the entire population, than in countries with means-tested, socalled 'residual' welfare state arrangements. The reason is that a greater number of population groups compete for benefits from the government in the former than in the

\footnotetext{
${ }^{2}$ Persson and Tabellini hypothesise that a fall in the dispersion of the distribution of factor income ('gross income') makes voters (along the lines of the median voter model) prefer less redistributive taxes. If this hypothesis makes sense, education policies reducing the dispersion of factor income would not only result in higher labour productivity among low-income groups, but also reduce the political demand for redistributive and distortionary taxes.
} 
latter type of society. Obvious examples of competing groups, then, are pensioners, unmarried parents, individuals with small children, public-sector employees, people living in owner-occupied houses, unemployed workers, individuals on long-term sick leave, and so on. Conflicts of interests among such socio-economic groups of voters tend to arise as soon as the 'veil of ignorance' of the individual's socio-economic position is lifted during the course of the life cycle. By contrast, 'overshooting' of welfare-state spending, as defined above, is not usually regarded as an issue in AngloSaxon countries, where welfare-state arrangements are more selective (less universal) than in other countries.

Formalized political theories emphasizing competition for benefits among socio-economic groups are often based on probabilistic voting models (rather than on the median voter model). In the special case when politicians are only interested in power per se, the announced pre-election policies of different parties converge on a utilitarian optimum, or a mean value of utility, rather than on the policy preferred by the median voter (Lindbeck and Weibull 1987). But if political parties are also motivated by policy preferences, such voting models instead predict that competing parties adopt different policy platforms in political equilibrium, and that the winning policy lies between a utilitarian optimum and the more popular party's preferred policy, and closer to the latter position (Lindbeck and Weibull 1993).

It is hardly controversial to say that both the explicit tax wedges and the implicit tax wedges in different benefit systems distort economic incentive although the magnitude of these distortions is controversial. I do not have much to add to the general discussion of how such distortions reduce economic efficiency and in some cases also retard economic growth. My only point is that a realistic analysis of this issue requires that we take account of the effects on a great number of individual decisions: leisure, household production, barter, the intensity and quality of work, promotion, work in the 'shadow economy', tax avoidance, tax evasion, the willingness of workers to shift among jobs, savings, the allocation of assets, and so on. The estimates of the 'deadweight costs' of tax distortions are, most likely, heavily underestimated if the analysis is confined to only one or a few of these decisions. ${ }^{3}$ It is also important to look at the implicit tax rates in various benefit programs since, in reality, these programs are

\footnotetext{
${ }^{3}$ Martin Feldstein (1995) has tried to catch the aggregate effects of several different market distortions in a single measure, namely income. He then comes up with much larger distortions than traditional
} 
not actuarially fair, in the sense that the capital value of expected benefits, in particular on the margin, often is much smaller than the expected capital value of contributions paid by the individual (directly or via the employer). For instance, if the capital value of my additional contribution to a certain social insurance system, such as the pension system, is $\$ 10,000$, while the capital value of my expected future benefit increase is $\$$ 5,000 , the implicit marginal tax rate is about 50 per cent. Naturally, it is also well known that social insurance is connected with 'moral hazard' problems, in the sense that some individuals adjust their behaviour to be able to draw on social insurance benefits, and that the authorities cannot observe or influence such behaviour adjustments.

It is particularly difficult for voters and politicians to realistically anticipate such aggregate disincentive effects of taxes and benefits if these effects only emerge after time lags. A trivial example is that it may take time for the individual to understand and react to changes in benefit and tax rules. Individual behaviour may also be constrained for a while by 'binding' institutional arrangements that adjust only after time lags, in response to changes in the economic incentives for individuals. For example, even if individuals may want to cut their working hours in response to more generous benefits for non-work and higher marginal tax rates on labour income (which makes the private costs of leisure lower than the social costs), such a cut may be difficult for them to make until labour market organizations or government legislation have (collectively) agreed to shorten the working hours (Lindbeck 1994). ${ }^{4}$ As a consequence, the effects of tax distortions are delayed, and politicians and voters may therefore support higher welfare-state expenditures and taxes than if no such lags existed. Indeed, such time lags (of uncertain length) also make it difficult for researchers to identify the effects of changes in taxes and welfare-state arrangements on individual behaviour, even in retrospect.

empirical studies, where the effects of distortions in the labour market are often measured by hours of work.

${ }^{4}$ Note that the economic distortion created by taxes is tied to the substitution effect and not to the income effect. There are, however, also two mutually counteracting income effects on labour supply: a 


\section{CHANGES IN SOCIAL NORMS AND POLITICAL PREFERENCES}

My main point about welfare-state dynamics is, however, that individual adjustments to changes in economic incentives are constrained by social norms for some time, and that some of the disincentive effects therefore materialize only after the norm adherence has weakened (Lindbeck 1995). It is reasonable to assume that norms in favour of work, or against living off handouts from others, initially emerged in societies where it was difficult to survive without working. The norms may have emerged either via an evolutionary process, when successful individuals were imitated by others, or via actions of specific 'norm senders', including parents, employers and colleagues. Before the emergence of the modern welfare state, such work norms therefore were quite consistent with, and indeed complementary to, the prevailing economic incentives.

Then came the welfare state, with generous benefits and high taxes. As long as earlier established norms were adhered to, these constrained potentially negative disincentive effects on work of higher taxes and more generous benefits for non-work. But it is reasonable to assume that tensions gradually built up between the norms inherited from the past and the new (weaker) economic incentives for work. As a result, some 'entrepreneurial' individuals started to exploit the new, generous welfare state arrangement by changing their behaviour in ways making these individuals qualify for benefits they had not previously been supposed to receive - a classical example of moral hazard.

This constitutes another conceivable explanation why disincentive effects of higher taxes and more generous benefits are likely to be stronger in the long than in the short run. We may then hypothesise that the strength of work norm tends to fall with the number of individuals living on benefits, in the sense that the guilt or shame connected with breaking the norms is then reduced (Lindbeck, Nyberg, and Weibull 1989). This is in particular likely to take place when the norm is 'social' in the sense of being upheld by the approval or disapproval of others. We would also predict that parents' incentives to instil work norms in their children fall if the taxpayers increasingly take over the future responsibility for the economic security of their children, via the build up of social insurance. Indeed, this prediction follows from a formal model of the family as a 
'norm sender' for its children (Lindbeck and Nyberg 2002). The enforcement of social work norms by the administrators of the social insurance system may also weaken over time when more individuals live on benefits, for instance as a result of unemploymentcreating macroeconomic shocks. ${ }^{5}$

So far, there has not been much systematic empirical research about social norms in connection with welfare-state policies. There is some general empirical documentation of the existence of social norms in favour of work, rather than living off government benefits. ${ }^{6}$ Such norms are often believed to be particularly strong in the case of highly selective benefits such as social assistance ('welfare' in U. S. terminology). For instance, Moffit (1983) has documented such norms, reflected in 'welfare stigma'. The stigma of living off 'universal entitlements' - such as unemployment benefits, paid sick leave and subsidised early retirement - is likely to be smaller than in the case of selective benefits. There may, however, be norms against 'over-using' or 'misusing' universal benefits. In other words, there may be norms limiting moral hazard and the cheating with benefits, respectively, also in the case of universal benefits.

Let us take unemployment benefits as an example. There is a strong case for generous unemployment benefits, since many individuals lose their jobs without any fault of their own. But the more generous the benefits, in particular the longer periods the benefits can be held, the more people will be unemployed at a specific point in time. Traditional economic analysis in terms of economic incentives and moral hazard takes us a long way in explaining this prediction. There is also empirical evidence on this issue; see Layard et al. 1991. It is, however, likely that social norms towards work, and endogenous changes in these, also play a part. For instance, Åberg, Hedström and Kolm (2003) find that an individual with given characteristics is more likely to be unemployed, and less likely to exit from unemployment, if aggregate unemployment in the individual's own neighbourhood is high. (The study refers to youths in 699 neighbourhoods in metropolitan Stockholm.) Moreover, on the basis of a study of attitudes in England, Clarc (2003) concludes that unemployed workers suffer less, psychologically, from their predicament if many 'relevant others' are also unemployed.

\footnotetext{
government spending.

${ }_{5}^{5}$ Lungqvist and Sargent (1998) have tried to explain unemployment persistence in Europe in the 1980s and 1990s by a gradually more lax administration of the unemployment benefit system. This may be interpreted as a weakening of the enforcement of work norms by the administrators of the system.

${ }^{6}$ Some of this literature is briefly summarised in Lindbeck and Nyberg (2003).
} 
Both studies are consistent with the notion that the social norms against living off unemployment benefits weaken when there is an increase in the number of individuals actually living that way. Hence, the studies are consistent with the hypothesis of endogenous social norms concerning work and the emergence of 'unemployment cultures'. Moreover, a sociological study for the Netherlands (Engbersen et al. 1993) in the late 1980s indicates that a substantial fraction of young, healthy persons living on benefits in that country regarded this way of life as a 'social right'. The authors interpret this as being consistent with the notion of 'benefit cultures' in some sections of the Dutch population, after a prolonged period of generous benefits and a large number of beneficiaries.

There is also a strong case for generous sick pay. But the more generous the sick benefits, the weaker the requirements of doctors' certification and the weaker the administrative controls, the greater number of individuals would be expected to be on sick pay at a given point of time. Sick-pay insurance is therefore also highly susceptible to disincentive effects and moral hazard. After all, to a considerable extent, the individual himself defines whether he is able to work or not. Several econometric studies conclude that a generous benefit rule, ceteris paribus, raises the incidence of sick leave (Drago and Wooden 1992, Johansson and Palme 2002, Persson 2003). It has, however, been difficult to explain the huge rise in the number of sick-pay beneficiaries in recent years (basically a doubling) in some countries, such as the Netherlands, Norway and Sweden by economic incentives alone. It has also been difficult to fully explain this development by changes in the composition of the labour force, or a deterioration of the health conditions of the population. ${ }^{7}$ It is also tempting to assume that a weakening of the social norms against using the sick pay system for other purposes than sickness plays a role. It is also difficult to explain the wide geographic variation in paid sick leave across regions and local communities within countries, such as Sweden, without references to geographic variations in norms against moral hazard and benefit cheating. Since work norms are likely to weaken only gradually in response to a rise in the number of beneficiaries, we would expect some time lag between changes in economic incentives and the incidence of sick leave. Indeed, in a study of the relation between the generosity of sick-pay benefits and sickness absentees in Sweden, Persson (2003) finds the effects to be stronger in the long than in the short run. 
Since the capacity to work rapidly falls by old age for some individuals, there is also a strong case for generous rules for early retirement for health reasons. But the more generous the rules, the more individuals will choose early retirement. Early retirement is therefore another field that is vulnerable to moral hazard. Empirical studies clearly indicate that generous conditions for early retirement tend to generate many early retirees (Gruber and Wise 1999) - an obvious example of the consequences of economic incentives and moral hazard. For instance, the effective retirement age in EU countries today is below 60 (and as low as 53 in Italy). As a result, the average employment rate in the EU in the age group 55-64 is only about 38 per cent. Another illustration is that about 12 per cent of the labour force in the Netherlands lived on disability pensions in the 1980s, without any evidence that the health situation in the Netherlands could possibly explain this. Although traditional economic incentives and moral hazard go far in explaining the high frequency of early retirement, it is also tempting to hypothesise that the social norms against applying for early retirement have been weakened by the rising number of individuals living on such benefits. Otherwise it would, once more, be difficult to explain the apparent geographical clustering of early retirement.

Moral hazard is also unavoidable in the case of economic support for single parents (in fact usually mothers). There is a strong social (humanitarian) case for government support to single parents, not least to mitigate the poverty of children in such households. But it is unavoidable that generous benefits encourage both divorce and birth outside marriage (or outside cohabitation) - another example of moral hazard. It is, however, also obvious that the social norms (stigmatisation) against single motherhood have gradually been weakened in the last decades of the $20^{\text {th }}$ century, although we do not know to what extent government support to single mothers has contributed to this development.

Outright benefit cheating is also unavoidable, for instance when individuals with unemployment benefits work in the black economy, and when others call in sick when, in fact, they have stayed at home to paint the flat, repair the summerhouse, help sick relatives or simply enjoy an additional holiday. This type of behaviour is not more surprising than tax cheating, which surprises nobody. It is also well known that some individuals receiving support because of single parenthood, in fact, do not live alone. While the existence of benefit cheating may largely be explained by economic

\footnotetext{
${ }^{7}$ For instance, about 8 per cent of the Swedish labour force stayed at home for asserted sickness on a
} 
incentives, we would expect the strength of the effect to depend on social norms, including the norm of honesty. Indeed, an opinion poll in Sweden in 2002 indicates that a majority of Swedes today think that it is OK to stay at home for asserted sickness, even without being sick - for instance because of family problems or because the individual regards his job, or his boss, as unpleasant (Modig and Boberg 2002). Moreover, administrative controls (via sampling) by the Swedish Insurance Board in 2001 found that 10 per cent of the individuals with paid leave for taking care of sick children were in fact at their jobs, or their children were at day care centres. Skogman Thoursie (2002) finds that a considerable number of males in Sweden haves called in sick when radio and television haves run international sporting games with an important participation of Swedish athletes. ${ }^{8}$

These fragmented examples of moral hazard and endogenous work norms, at least, suggest that the issue is worth a more systematic empirical research. The examples also suggest that induced changes in social norms may be important not only in the case of 'selective' (or residual) welfare states (with means test), but also for the so-called 'universal' welfare state - hence, when benefits are tied to citizenship or residence rather than low income. Indeed, the distinction between these two types of welfare states is often strongly exaggerated in the literature. 'Deserving' beneficiaries must be sorted out from 'non-deserving' ones by discretionary administrative decisions, not only in the case of selective benefits but also in the case of universal ones. For instance, the authorities must find out who among the claimants of 'universal' benefits for unemployment, sickness, disability, single parenthood, and so on, really qualifies for such benefits according to the rules.

As a result, in a long perspective, it is not self-evident that the administration costs are smaller in universal than in selective systems. They are probably smaller per person, but it may be necessary for the authorities to control many more individuals in a universal than in a selective welfare state. An advantage, though, of universal as compared to means-tested benefits is that the implicit marginal tax wedge will be

\footnotetext{
given day in the year 2002 (Persson 2003).

${ }^{8}$ Among males, approximately 16 per cent more than normal reported sick in connection with two international skiing competitions reported on TV and radio (World Championship and Olympic Games).
} 
smaller for low-income earners. But the marginal tax rates will instead be higher for the general taxpayer. ${ }^{9}$

So far, I have concentrated on changes in market behaviour. Voting behaviour may, however, also be influenced by existing welfare state arrangements, since those living off benefits have a greater interest than others in supporting generous benefit rules and high taxes. When we consider the possibility that social norms change with the number of beneficiaries, a society may wind up in quite different political equilibrium positions, depending on the previous path of welfare-state spending. If benefits are only moderately generous and the norms against living off benefits are strong at a given point in time, a vast majority of voters are likely to support policies with only moderate benefit levels (and taxes). However, if for some reason the economy has wound up in a situation with a great number of transfer recipients, for instance, after a huge negative macroeconomic shock, the adherence to work norms is likely to weaken after a while, and more voters will support generous benefits (and hence higher taxes).

Indeed, multiple equilibria of this type have been formally modelled in the literature. In a theoretical model by Lindbeck, Nyberg and Weibull (1999) with homogenous preferences, there is a critical wage rate that separates individuals choosing to live on benefits and individuals choosing to work. Assuming, for simplicity, that everyone can predict the consequences for the number of beneficiaries of policy changes, there turns out to be only two alternative political equilibria - a lowtax equilibrium, where most individuals work, and another high-tax equilibrium, where a majority of voters live on benefits. Alternatively, we may assume that individuals differ in their sensitivity to social norms. In this case, there will instead be a critical value for the intensity of guilt or shame, when breaking the existing social norms, that separates individuals. ${ }^{10}$

In principle, at some point of time a society may 'flip' from the first to the second type of economic-political equilibrium. One example is when a huge negative macroeconomic shock has thrown a large fraction of the population into various safety

\footnotetext{
${ }^{9}$ Means test exists also in countries emphasizing universal welfare state arrangements. Examples are social assistance, income-dependent housing subsidies and income-dependent fees for services such as childcare and old-age care.

${ }^{10}$ Multiple political equilibria of 'boot-strap' type, without social norms, have been analysed by Hassler et al. (2003). In this model, the multiplicity comes from the assumption that voters rationally expect investment in human capital today to influence voters' interest in redistribution policies in the future.
} 
nets. It may be difficult to get a political majority for less generous benefits after such events. ${ }^{11}$ Another example is when voters and politicians turn out to have underestimated the long-term disincentive effects (including moral hazard) of taxes or benefits, and perhaps also the weakening of social norms when the number of beneficiaries increases. We do not yet know much about the empirical relevance of these hypotheses and inferences.

Naturally, aggregate political preferences may change also in other respects as a result of the previous path of government spending and taxes. For instance, suppose that subsidies of childcare and old-age care outside the family have induced a great number of females to move into the labour market. As a result, some of them may have learnt to appreciate economic independence and non-monetary benefits of work outside the household more. After all, preferences are, to a large extent, a social phenomenon. There may naturally also be reverse causation: 'spontaneous' (unexplained) increases in preferences among females for economic independence and work outside the household may boost their political demand for subsidised childcare and old-age care. Ideological developments, including feminism, may lie behind such spontaneous changes in preferences. In reality, mutual interaction between spontaneous changes in preferences and induced changes in preferences in response to new experiences is probably the most proper way of looking at the issue.

We may also speculate that the respect for the existing distribution of disposable income tends to recede gradually when people learn that this distribution is, to a large extent, politically determined - via taxes and welfare state benefits - rather than market determined by the distribution of skills and efforts of individuals (Lindbeck 1994). As a result, political taboos against government intervention to redistribute income may gradually recede. The legitimacy of remaining income differentials is then likely to fall. As a result, political conflicts about the distribution of income may increase rather than fall. Thus, I hypothesise (speculate) that conflicts about the distribution of income may be large, not only in societies with huge income differences (as predicted by the median voter model) but also in societies with a rather even distribution of disposable income, if the latter is a result of progressive taxes and transfers. In other words, I hypothesise that distributional conflicts do not necessarily fall monotonically with a reduction in the

\footnotetext{
${ }^{11}$ Formally, a process of the 'unwinding' of social norms is rather similar to certain types of ecological processes. Initially, ecological disturbances may hardly be noticeable, but they may speed up after a
} 
dispersion of the distribution of disposable income, when this reduction is due to tax and welfare state policies. For instance, it is my impression that the huge gradual squeeze of the distribution of disposable income in Sweden from the late 1950s to the mid-1980s was accompanied by larger rather than smaller political conflicts about the remaining income differentials. It should be possible to investigate if this hypothesis is consistent with empirical data about redistributional conflict in the political arena.

It is also likely that social norms on saving are influenced by welfare state policies. Before the emergence of the modern welfare state, individuals had probably learned from experience that it is proper to save for rainy days and old age. Subsequently, however, more and more generous welfare-state arrangements made voluntary saving for dealing with such contingencies less important. As in the case of work norms, it is therefore likely that the adherence to saving norms only gradually subsided when the government started to provide individual income security. This assertion is consistent with the experience that voluntary household savings only fell slowly in Sweden after the initiation of the new, quite generous government pension system in 1960 (the ATP-system).

We may also speculate that welfare-state arrangements have consequences for entrepreneurship, which certainly is an important element of economic dynamics. It is sometimes argued that entrepreneurship is stimulated by welfare state arrangements, since failed entrepreneurs are asserted to be protected by unemployment benefits and social assistance. In other words, it is assumed that the risk of entrepreneurship is reduced by welfare state arrangements; see, for instance, Sinn (1996). But do entrepreneurs really regard unemployment benefits and social assistance as important alternatives ('fall back positions') to entrepreneurial success? Is it not more likely that they believe that they can support themselves as employees if they fail as entrepreneurs? Moreover, in many countries, entrepreneurs are not even covered by the unemployment insurance system.

I would, therefore, hypothesise that other features of the welfare state than the safety nets are more important for entrepreneurship. For instance, the Alesina-Perotti argument that social policies may contribute to social and political stability is relevant not only for investment in incumbent firms, but also for new entrepreneurship. On the other hand, the after-tax return for entrepreneurial activities may be so small in a high- 
tax society that entrepreneurship is seriously harmed. ${ }^{12}$ We would also expect low household savings to have negative consequences for entrepreneurship, since investment in new and small firms often requires personal equity capital obtained outside the stock market.

This is not the whole story, however. Since entrepreneurs try and sometimes also succeed in building up personal wealth, they may be regarded as 'alien' figures in societies with advanced welfare states that emphasize income equality. The social acceptance of entrepreneurs may therefore unfold in highly egalitarian in welfare states, and this is likely to harm entrepreneurship. This may occur both directly via the attitudes in society towards entrepreneurs and indirectly via political decisions that are induced by these attitudes. Indeed, studies in Sweden during the 1970s and early 1980s revealed quite negative attitudes towards entrepreneurship and entrepreneurs among the population (Henrekson and Jakobsson, 2001). In 1978, only 30 per cent of the respondents in an opinion study in Sweden believed that it was 'important to encourage entrepreneurship'. Moreover, only 37 per cent believed that business leaders (entrepreneurs) were 'capable of running firms most efficiently'; a majority believed that government officials or union leaders would be more capable to run them. These negative views were proceeded and accompanied by a legislation and taxation making entrepreneurship less rewarding, and more administratively difficult. (The situation has subsequently changed considerably.)

\section{REFORMS AND RETREAT OF THE WELFARE STATE}

Welfare-state dynamics is potentially important not only in order to understand the emergence of today's welfare-state arrangements, but also when analysing how such arrangements are subsequently reformed or cut down. Well-known situations when this may happen are when existing welfare-state arrangements encounter financial difficulties; when serious disincentive effects emerge for the domestic economy; and when new socio-economic developments make existing welfare-state arrangements less relevant than before.

\footnotetext{
instance of weather conditions.

${ }^{12}$ For instance, the marginal tax rates in Sweden for small firms approached one hundred per cent in real terms in the 1970s and 1980s, if all taxes are considered (Du Rietz, 1994).
} 
An obvious situation when the welfare state runs into serious financial difficulties is when the domestic economy is exposed to unexpected shocks, for example unfavourable demographic developments, slower productivity growth, or unemployment-creating macroeconomic disturbances. The creation of generous welfare-state arrangements in the 1960s and 1970s was based on quite optimistic assumptions about the future growth of the general tax base. It is therefore easily understood that the subsequent slowdown of GDP growth created financial problems for several welfare-state arrangements, and that suggestions for reforms and retreats of such arrangements thus have emerged. The most usual policy responses to restore financial viability seem to have been reduced replacement rates (that is simply lower benefits and hence more coinsurance), more waiting days and shorter periods of time during which benefits can be obtained (including a higher retirement age). Such retreats of the generosity of social insurance have taken place, for example, in the case of sick pay, unemployment benefits and pension.

While the financial vulnerability of the welfare state to shocks is relatively easily to detect, disincentive effects are more difficult to observe and measure. Indeed, the first instinct of many proponents of generous welfare-state arrangements is to deny that such problems actually exist, or at least that they are important. Some countries have, however, recently started to reform their welfare-state arrangements and the financing of these as a result of conceived disincentive problems. The most obvious example is the rather comprehensive tax reforms in several countries in the 1980s and 1990s, which were usually designed to broaden the tax base, reduce the tax rates and mitigate the progressivity of the tax system. The most frequently suggested and implemented reforms of benefit systems (including social insurance) have simply been higher contribution rates, benefit cuts and (in the case of the pension system) a higher retirement age. Some countries have, however, also strengthened the link between the individual's lifetime contributions and his subsequent pension benefits - hence a shift to what may be called a 'quasi-actuarial' pension system (Lindbeck and Persson 2003).

Socio-economic developments that have made existing welfare-state arrangements less appropriate include increased labour force participation of married women and the increased instability of the family, the latter most dramatically reflected in higher divorce rates. Naturally, such developments do not only constitute the background for the demand for a greater provision of organized child care and old-age 
care outside the family, but also for suggestions to tie welfare-state benefits to the individual rather than the family.

Higher income and better-educated individuals also generate political demand for more differentiated systems of income protection and social services, as well as for increased individual choice. This development may be regarded as a parallel to an increased demand for differentiated consumer goods as a result of similar forces. In the case of income insurance, recent shifts to contribution-based systems with individual accounts in some countries may be seen as a response to these new demands. Such developments are particularly noticeable in the pension system. In the case of social ('human') services, the new demands for individualization are probably easiest to satisfy if government subsidies of such services 'follow' the individual's own choice of service provider (that is 'voucher systems' in the broad sense of the term). However, increased individualization of welfare-state arrangements are bound to encounter strong political resistance from groups having traditionally regarded the uniformity of welfarestate arrangements as an advantage, partly because such uniformity is seen as a reflection of egalitarian values.

When discussing retreats of welfare-state spending, certain asymmetries between the politics of expansion and retreat, respectively, are exposed. While the combination of selective benefits and general taxes, as argued above, tends to boost the expansion of government spending, the same combination is likely to make it difficult to cut already existing benefits. Thus, there may be some irreversibility because of special features of the political process. Moreover, every new type of benefit tends to create a new interest group of beneficiaries, which accentuates the irreversibility. Individuals are also likely to be more dissatisfied when losing benefits they already have than if not getting such benefits in the first place. Indeed, this point may be regarded as a simple application of the Tversky-Kahneman prospect theory (1981), according to which the utility function is steeper to the left than to the right of the individual's initial position. Strong voter resistance to benefit cuts has also been recorded in numerous opinion pulls and is, of course, highly noticeable in the actual political process. Today, Sweden is an extreme example, since about 60 per cent of the population get practically all their income from the government - either as employees in the public administration and service production, or as transfer recipients (Lindbeck 1997). 
Another complication with reforms and retreats of welfare-state spending is that such arrangements constitute a tightly interlocked network. It is difficult to remove one arrangement without complications for other arrangements. One illustration is that cuts in one type of benefit induce individuals to shift to other types. An illustration is that people in Sweden switched from sick leave to work injury leave in the late 1980s, when the replacement rate in the latter system was raised to 100 per cent of the previous income as compared to 90 per cent in the case of sick leave. Similar shifts from unemployment benefits to sick leave benefits and early retirement have recently been noticed. Such shifts are particularly likely if social norms against 'over-using' or 'misusing' benefits have weakened.

Moreover, disincentive effects of generous benefits are often mitigated by other elements of a benefit system. Disincentive effects may therefore be reduced if these elements are accentuated. An obvious example is a stiffening of requirements for doctors' certificates and administrative controls in the homes and at the work place in the sick-benefit system.

We would also expect that constitutional factors influence the political feasibility of reforms and retreats of welfare-state spending. Some political scientists (Bonoli 2001, Swank 2001, Huber and Stephens 2001) argue that centralised political regimes, often with majority voting (such as the UK and New Zealand), have been able to make more dramatic reforms and retreats of welfare-state arrangements than more decentralised political regimes (often with proportional representation). Indeed, reforms and retreats in the UK and New Zealand, with majority parties, were made without an acute macroeconomic crisis, although both countries had experienced long periods of relative economic declines, which have often (realistically) been assumed to depend, at least to some extent, on government-created economic distortions. But the same authors also observe that some countries with quite fragmented political regimes have also been able to negotiate substantial reforms and retreats, such as Denmark and the Netherlands and, to some extent, also Finland and Sweden. It might be argued, however, that the reforms and retreats in these countries were facilitated by acute economic crisis, partly as a result of severe negative macroeconomic shocks.

The internationalisation of markets is often also regarded as a factor behind recent reforms and retreats of the traditional welfare state, which has basically been a 'national project'. Clearly, individual nations can no longer have much higher corporate and capital income tax rates than other counties. There has, indeed, recently been a race 
to a 'common level' of taxation in this field - in fact to the neighbourhood of about 30 per cent. The consequences for the possibilities to finance of the welfare state are, however, rather limited, since it is basically financed by the taxation of labour rather than capital. Although there is not (at least not yet) a 'race to the bottom' of taxation and social assistance in general, the internationalisation process clearly limits the ability of national governments to redistribute income among income classes.

We also expect increased mobility of people from poor to rich countries to induce the latter to continue, or even sharpen, their strict immigration control in order to limit the number of individuals expected to claim social benefits of various types. In principle, an internationalisation of the markets for highly educated labour may also induce countries to reduce the progressivity of the tax system, although there are hardly any strong tendencies yet in this direction. (Reductions in the maximum marginal tax rates in the 1980s and 1990s seem to have been induced mainly by domestic rather than international considerations.)

In a world with higher geographical mobility of labour, we would also expect political demand for increased geographical 'transportability' of national welfare-state entitlements and the provision of services - within as well as across nations. In the case of social insurance, these demands are probably easiest to satisfy in the context of contribution-based systems with individual accounts, which are 'tied' to the individual regardless of where he lives. In the case of social services, such as medical care or oldage care, a way to satisfy the demand for international transferability might be to request that the social insurance system in one country pays the bills for its citizens also when they get their services in other countries. This would simply be an international extension of the 'voucher method' to finance and allocate social services.

It is today too early to say whether the continuing internationalisation of the economic system will result in more far-reaching coordination of welfare-state arrangements and their financing across nations. The alternative to formal coordination ('harmonization') is, of course, that individual countries independently adjust their systems to the ever more international character of markets for products, services, labour and capital - 'system competition' rather than centralized coordination. Most likely, there will be some combination of these two developments. 


\section{REFERENCES}

A. Alesina and D. Rodrik, 'Distributive Politics and Economic Growth', Quarterly Journal of Economics, 109 (1994) 465-90.

G. Bonoli, 'Political Institutions, Veto Points, and the Process of Welfare State Adaption', in P. Pierson, op.cit., pp. 238-64.

A. E. Clark, 'Unemployment as a Social Norm: Psychological Evidence from Panel Data', Journal of Labor Economics, 21 (2003) 323-51.

R. Drago and M. Wooden, 1992, 'The Determinants of Labor Absence: Economic Factors and Workgroup Norms across Countries', Industrial and Labor Relations Review, 45 (1992) 764-78.

G. Du Rietz, Välfärdsstatens finansiering, Socialstatsprojektet 1994.1 (Stockholm: City University Press, 1994).

G. Engbersen, K. Schuyt, J. Timmer and F. Van Warden, Cultures of Unemployment: A Comparative Look at Long-Term Unemployment and Urban Poverty (Boulder, CO: Westview Press, 1993).

G. Esping-Andersen, The Three Worlds of Welfare Capitalism (Cambridge: Polity, 1990).

M. Feldstein, 'The Effects of Marginal Tax Rates on Taxable Income: A Panel Study of the 1986 Tax Reform Act', Journal of Political Economy, 103 (1995) 551-72.

M. Frankenhaeuser, U. Lundberg and M. Chesney (eds), Women, Work, and Health: Stress and Opportunities (New York: Plenum, 1991).

J. Hassler, J. V. Rodríguez Mora, K. Storesletten and F. Zilibotti, 'The Survival of the Welfare State', American Economic Review, 93 (2003) 87-112.

J. Gruber and D. A. Wise (eds), Social Security and Retirement around the World, (Chicago: University of Chicago Press, 1999).

P. Hedström, A.-S. Kolm, and Y. Åberg, 'Social Interactions, Endogenous Processes, and Youth Unemployment', Manuscript, Department of Sociology, Stockholm University, 2003.

M. Henrekson and U. Jakobsson, 'Where Schumpeter Was Nearly Right - the Swedish Model and Capitalism, Socialism and Democracy', Journal of Evolutionary Economics, 11, (2001), pp. 331-358.

E. Huber and J. Stephens, 'Welfare State and Production Regimes in the Era of Retrenchment', in P. Pierson, op. cit., pp. 107-145. 
P. Johansson and M. Palme, 'Assessing the Effect of Public Policy on Worker Absenteeism', The Journal of Human Resources, XXXVII (2002) 381-409.

R. Layard, S. Nickell and R. Jackman, Unemployment: Macroeconomic Performance and the Labour Market (Oxford: Oxford University Press, 1991).

A. Lindbeck, 'Redistribution Policy and the Expansion of the Public Sector', Journal of Public Economics, 28 (1985) 309-28.

'Overshooting, Reform and Retreat of the Welfare State', Tinbergen Lecture, De Economist, 142 (1994).

'Welfare State Disincentives with Endogenous Habits and Norms', Scandinavian Journal of Economics, 97 (1995) 477- 94.

'The West European Employment Problem', Weltwirschaftliches Archiv, (Dec 1996) 1-31.

'The Swedish Experiment', Journal of Economic Literature (1997) 1273319.

'Changing Tides for the Welfare State - An Essay', Research Institute of Industrial Economics (IUI), Working Paper No 550 and IIES Seminar Paper No 694, Stockholm 2001; forthcoming in Festschrift for Richard Musgrave, BerlinHeidelberg: Springer-Verlag.

'From the Cradle to the Grave, A prescription for reform of European welfare states over the individual's life cycle'. A publication in Skandia's Social Focus series, Stockholm 2002.

'Social Model: Lessons for Developing Countries', in R. Pethig and M. Rauscher (eds), Challenges to the World Economy, Festschrift for Horst Siebert (Berlin-Heidelberg: Springer-Verlag, 2003), pp. 67-79.

A. Lindbeck and S. Nyberg, 'Raising Children to Work Hard: Altruism, Work Norms and Social Insurance', CESifo Working Paper No. 498, Munich 2001.

A. Lindbeck, S. Nyberg, and J. W. Weibull, 'Social Norms and Economic Incentives in the Welfare State', The Quarterly Journal of Economics, 114 (1999) 1-35.

A. Lindbeck and M. Persson, 'The Gain from Pension Reform', Institute for International Economic Studies, Seminar Paper No. 712 and IUI Working Paper No. 580, Stockholm 2002.

A. Lindbeck and D. S. Snower, The Insider-Outsider Theory of Employment and Unemployment (Cambridge, MA: MIT Press, 1988). 
A. Lindbeck and J. W. Weibull, 'Balanced-Budget Redistribution as the Outcome of Political Competition', Public Choice, 2 (1987) 273-97.

'A Model of Political Equilibrium in a Representative Democracy', Journal of Public Economics, 5 (1993) 195-209.

L. Ljungqvist and T. J. Sargent, 'The European Unemployment

Dilemma,' The Journal of Political Economy, 106 (1998) 514-50.

A. Meltzer and S. Richard, 'A Rational Theory of the Size of Government', Journal of Political Economy, 89 (1981) 914-27.

A. Modig and K. Boberg, TEMO, T22785, Stockholm 2002.

R. Moffit, 'An Economic Model of Welfare Stigma', American Economic Review, (Dec. 1983) 1023-35.

G. Myrdal, An American Dilemma (New York: Carnegie Foundation, 1944), Appendix 3.

M. Persson, 'Sjukskrivningarna och ersättningsnivån', in B. Swedenborg (ed.), Varför är svenskarna så sjuka? (Stockholm: SNS förlag, 2003).

T. Persson and G. Tabellini, 'Is Inequality Harmful for Growth?', American Economic Review, 84 (1994) 600-21.

Economic Policy in Representative Democracies, book manuscript, Institute for International Economic Studies, Stockholm 2002.

P. Pierson, (ed.) The New Politics of the Welfare State (Oxford: Oxford University Press, 2001).

H.-W. Sinn, 'Social Insurance, Incentives and Risk Taking', International Tax and Public Finance, 3 (Jan. 1996) 296-80.

P. Skogman Thoursie, 2002, 'Reporting Sick: Are Sporting Events Contagious?', mimeo, Department of Economics, Stockholm University, Sweden.

D. Swank, 'Political Institutions and Welfare State Restructuring. The Impact of Institutions on Social Policy Change in Developed Democracies', in P. Pierson, op. cit., pp. 197-237.

A. Tversky and D. Kahneman, 'The Framing of Decisions in the Psychology of Choice', Science, 211 (1981) 453-58.

A. Wildavsky, The Politics of the Budgetary Process (Boston: Little, Brown, 1984). 